\title{
Beyond Cultural and Historic Values, Sustainability as a New Kind of Value for Historic Buildings
}

\author{
Belén Onecha ${ }^{1, *(\mathbb{D}}$, Alicia Dotor ${ }^{2}$ and Carlos Marmolejo-Duarte ${ }^{3} \mathbb{D}$ \\ 1 Architecture Technology Department, Barcelona School of Architecture, Polytechnic University of Catalonia, \\ 08028 Barcelona, Spain \\ 2 Independent Researcher, 08028 Barcelona, Spain; adotor@coac.net \\ 3 Centre for Land Policy and Valuations, Architecture Technology Department, Barcelona School \\ of Architecture, Polytechnic University of Catalonia, 08028 Barcelona, Spain; carlos.marmolejo@upc.edu \\ * Correspondence: belen.onecha@upc.edu; Tel.: +34-93-401-6385
}

Citation: Onecha, B.; Dotor, A.; Marmolejo-Duarte, C. Beyond

Cultural and Historic Values,

Sustainability as a New Kind of Value for Historic Buildings. Sustainability 2021, 13, 8248. https://doi.org/ $10.3390 /$ su13158248

Academic Editors: Kristian Fabbri and Marianna Rotilio

Received: 4 June 2021

Accepted: 15 July 2021

Published: 23 July 2021

Publisher's Note: MDPI stays neutral with regard to jurisdictional claims in published maps and institutional affiliations.

Copyright: (c) 2021 by the authors. Licensee MDPI, Basel, Switzerland. This article is an open access article distributed under the terms and conditions of the Creative Commons Attribution (CC BY) license (https:/ / creativecommons.org/licenses/by/ $4.0 /)$.

\begin{abstract}
In attempts to improve the energy efficiency of protected historical buildings, two barriers arise. The first is the restrictions imposed by authorities that are responsible for cultural heritage preservation. The second is the exclusion of protected buildings from strict compliance with energy efficiency requirements in current regulations, such as the issue of an Energy Performance Certificate, which removes them from conventional channels of public policies. Both of these issues put heritage in a delicate situation, especially when they are intended for privately developed residential uses. This paper presents a methodology for assessing and establishing a trade-off between energy performance and the cultural value of heritage buildings through the comprehensive analysis of a case study: the retrofitting of Can Armengol Palace in Palma de Mallorca (Spain). The study revealed (1) the need to objectify the cultural values of the building as far as possible to identify conflicts with the strategies of energy efficiency improvement; and (2) the appropriateness of considering every aspect of a rehabilitation intervention in a global simultaneous approach, not just energy aspects. The method that was used had five steps: acquiring a deep knowledge of the building configuration, assessing the building performance for every legal requirement, identifying cultural values, defining intervention criteria, and analyzing intervention effects on the protected elements of the building. The most important contribution in this study is the detailed and extended definition of architectural heritage values and the consideration of interventions resulting from sustainability retrofits as a new kind of value, that reflects current worries, for which future generations will remember us.
\end{abstract}

Keywords: heritage buildings; energy efficiency; residential uses; sustainability value; historic values

\section{Introduction}

\subsection{Purpose and Significance of the Work}

Legislation on energy efficiency has evolved rapidly in very little time, especially if we compare it with other building-related laws, such as structural, fire safety, noise, and damp protection regulations, which have mainly remained stable. However, the rapid evolution has not affected the original exclusion of protected buildings from energy performance requirements, regardless of their protection level.

The Energy Performance of Building Directive (EPBD 2002/91/EC), revised in 2010 (EPBD recast 2010/31/EU), introduced stricter building regulations for new premises and deep renovations, and energy performance certificates (EPC) to incentivize the renovation of existing buildings. In addition, the Energy Efficiency Directive (2012/27/EU) established a set of binding measures to help the EU reach its objectives, these measures included the mandatory energy efficiency certificates accompanying the sale and rental of buildings. The 2012 EED was amended in 2018, introducing a new headline energy efficiency target for 2030 of at least $32.5 \%$ and concepts like the European Green Deal, meaning that the EU aims at becoming the first climate-neutral continent by 2050 . Interestingly, in national 
transpositions such as those in Spain, protected buildings are excluded from the mandatory application of these policies. Such an exclusion has an impact on intensively used historic buildings and heritage buildings that are privately owned or have been included in the real estate market to make their preservation feasible. A growing body of literature has shown evidence of market premiums for high-level EPC residential buildings [1]. In turn, the higher value of efficient premises incentivize owners and developers to invest in efficient technologies. To explain the price increases, researchers have argued the existence of benefits such as energy savings, environmental conservation, and joint benefits in the form of comfort and health preservation [2]. In brief, increased user wellbeing renders greater willingness to pay for efficient buildings (WTP). However, WTP is contingent on environmental awareness, education attainment, and income. In general, the higher the levels of the aforementioned characteristics, the higher the WTP [3,4]. Interestingly, households that have higher levels of these characteristics also show interest in buying, leasing, and renovating privately owned historic buildings or simply living around them. Thus, excluding such buildings from conventional renovation polices can reduce their acceptability and, in turn, their preservation. This risk is increased in countries such as Spain where specific targeted financial policies to retrofit historic buildings are largely absent.

It may seem reasonable to prioritize preservation of the cultural values of heritage over their energy performance. However, what may be reasonable when it is expressed in broad terms can be confusing when it is applied to specific aspects. For buildings that are used occasionally, such as cultural premises, a reduction rather than an exemption from these requirements could be understood. Adaptive thermal comfort and users understanding the priority of protecting cultural values during short visits may offset lower energy demands [5]. However, when continually used buildings like dwellings are considered, the exigence on energy efficiency is inescapable. Non-compliance with energy performance measures may result in abandonment of the historic building due to high maintenance costs or lack of comfort, health-related issues, and lack of competitiveness compared to new and retrofitted nZEB buildings.

Historic dwellings built before the First World War represent $22.69 \%$ of buildings in the EU $[6,7]$ and are precisely those with the highest carbon emissions and energy demand. Consequently, there is a clear need for stricter performance measures for these buildings and careful assessment of how they are affected by cultural value criteria. This is particularly true when energy efficiency also implies joint public benefits in the form of energy security, environmental preservation, job creation, and public health. Therefore, the balance between cultural preservation and energy retrofits should consider the following possibilities.

Offer new opportunities for protected historic buildings that comply with market preferences and public policy requirements, including their use as public and private housing.

Improve the health and welfare of occupants, which is closely linked to the building's energy performance.

Preserve every historical phase of the building, not in line with a frozen image of the building past, but adding the careful and sensible expression of the current period of history, that of sustainability.

Find a balance between cultural protection, reduction in consumption, and suppression of carbon emissions.

Throughout this first part of the paper, the difficulties still existing in improving energy efficiency in heritage buildings have been summarized.

\subsection{Context}

Although research on the energy efficiency of historical buildings has increased significantly over the last few years, there are still many obstacles to the dissemination of the main intervention strategies. Historical buildings will not become sustainable until there is a balance between an improvement in energy performance and the preservation of cultural values.

Below, the most relevant studies on this subject are reviewed briefly. 


\subsubsection{Main Obstacles to Achieving Energy Efficiency in Protected Historic Buildings}

The interest that has motivated existing research in this area arises from: (1) when referring to protected or heritage architecture, buildings permits can be obtained with less strict requirements, which means that renovation can be done without fulfilling the same level of improved energy efficiency that the rest of buildings [8], and (2) the challenges of finding feasible solutions that enable an improvement in energy performance to be combined with the preservation of the building envelope cultural values, when this last is priority $[9,10]$.

It is difficult to rigorously establish the thermal performance of historic buildings. Cornaro et al. [11] suggested that the most suitable methods of simulating their energy performance are dynamic ones. Such methods allow parameters like thermal inertia to be considered, subject to the availability of detailed data on the weather and the construction configuration of the building, which are key aspects. However, discrepancies between simulated and real behavior can be observed for both new and existing buildings, with the largest differences being for the latter. The major limitations in their simulation are the lack of reliable information on the thermo-physical features of the technological components, the difficulties in describing geometric shapes, and the inconsideration of certain physical phenomena $[11,12]$. Related to this, some researchers have gone through the validation of hygrothermal simulation models of historical buildings based on microclimate parameters [13].

Moreover, user behavior is difficult to integrate into any methodology. While a successful pre-intervention experience of a methodology based on the "design-driven approach" in order to make the inhabitants "collaborators" of the retrofitting project exists [14], the post-intervention user behavior is hard to predict. This is probably because the combination of situations is multiple and diverse, especially in residential use [15-17].

Nonetheless, authors agree that including historic buildings, particularly those with residential use, in legislation on energy modernization would have great benefits and contribute to the sustainable survival of historic city centers. Currently, the high cost of energy consumption and low levels of thermal welfare are leading to the abandonment of buildings and/or producing social inequality $[9,15,18]$.

\subsubsection{Intervention Strategies to Improve the Energy Performance of Historic Buildings}

A usual strategy resulting from an understanding of difficulties in insulating the envelope consists of implementing active systems. While this solution may make premises efficient if high-efficiency systems are used, it neglects the potential of the building from a bioclimatic perspective. Furthermore, this strategy has a great disadvantage as it has a considerable impact on user perceptions of the historic context of the building.

Researchers increasingly consider that the most suitable strategy to improve the energy efficiency of historic buildings is to correct the thermal performance of the envelope through the addition of specific insulating layers. Two trends can be found in opinions on this solution. The first absolutely trusts thermal insulation placed over the interior face of the envelope. The second stresses the problems that arise from placing insulation on the interior face of the envelope and supports better knowledge of the thermal performance of the envelope, particularly its thermal inertia, to enhance it and thus ameliorate the general energy efficiency of the building. These divergent perspectives are explained below.

Improvement of the Envelope's Thermal Performance through Insulation

Authors who support this strategy argue that energy efficiency must be achieved mainly by reducing demand [19]. This option has a significant number of supporters, who suggest that measures implemented on the envelope should be combined to reduce thermal transmittance. Most of these authors agree that thermal insulation should be placed on façades, roofs, and slabs; windows should be replaced by others that are airtight with double or triple glazing; and solutions should be developed for solar protection. These strategies have the longest payback, although they benefit from government financial 
incentives. Some authors even suggest that these measures should be combined with clean energy production $[10,20,21]$.

Most authors agree that thermal insulation can only be placed on the interior face of the envelope to avoid any impact on the cultural values represented by the façades and roof of the building. All of them accept the risk of permanent dampness on the envelope behind the insulation, as much due to condensation from interior humidity as from periods of continuous rain that eventually saturate the entire thickness of the wall. Accordingly, a new problem emerges: the growth of microbes that can enter the indoor air and affect occupants' health. To avoid these complications, they recommend hygroscopic interior coatings, installing a vapor barrier, or external waterproof coatings. The solution that is chosen depends on the interior occupation rate of the building and the climatic conditions $[9,20,22]$.

The RIBuild European project established a method to determine whether a building is suitable for internal insulation depending on the materials, the climate, etc. [8], while the HELLO European project's main purpose was to contribute to data available in the literature on the real hygrothermal behavior of historic walls and the suitability of insulation technologies [23].

Improvement of the Thermal Behavior of the Envelope through Better Comprehension of Thermal Inertia

Another group of experts point out that historic buildings are already bioclimatically designed according to climatic and environmental conditions to provide thermal comfort in the absence of mechanical systems [24]. Consequently, greater knowledge must be acquired of the thermal behavior of the buildings' construction elements. In particular, knowledge is needed on their thermal inertia, which is also related to aspects like solar radiation, relative humidity, and wind speed. A lack of knowledge of thermal inertia can result in inappropriate thickness of thermal insulation, leading to greater energy consumption and lower thermal comfort $[25,26]$. Several authors have shown that proper use of thermal inertia can reduce heating and cooling demand $[27,28]$. Few authors have monitored historic buildings to learn the real thermal inertia of their envelope. The existing monitoring studies show that the thermal behavior of walls differs from, and mostly overcomes, the theoretical assumptions in handbooks [29,30]. A number of experts stress the indoor overheating produced during the summer due to interior insulation of the envelope [31,32]. Some of them even add that interior insulation also causes permanent moisture, a larger quantity of volatile contaminants, and radon pollution, with no other solution than a mechanical ventilation system $[33,34]$.

\section{Energy Efficiency, Thermal Comfort, and Interior Environmental Comfort}

References to historic buildings' sustainability usually only focus on energy efficiency and the reduction of carbon emissions [35]. They frequently overlook other key aspects such as indoor environmental quality (IEQ). IEQ for dwellings usually considers thermal comfort, lighting, and acoustic comfort as much as indoor air quality [35]. These factors have a direct impact on users' health [34,36-38]. Furthermore, heritage value conservation is a specific point of EIQ when considering the preventive conservation approach. This has been taken into account for cultural heritage buildings like museums or higher education [39-41].

In addition, the achievement of energy efficiency in a historic building does not imply the achievement of proper thermal comfort or even a reasonable IEQ [38]. Geng et al. [42] studied the effects of thermal comfort on IEQ perception and user productivity. For this purpose, they considered indoor temperature as a variable parameter ranging between $16^{\circ} \mathrm{C}$ and $28^{\circ} \mathrm{C}$, and other fixed parameters such as $\mathrm{CO}_{2}$ concentration, lighting, and noise level. They concluded that thermal variation influenced thermal comfort and perceptions of the other IEQ factors: when thermal comfort was unsatisfactory, the perceived comfort for the rest of IEQ variables was lower, and vice versa [42]. 
Few studies have considered all IEQ variables together. Most of them center on temperature, relative humidity, or ventilation, sometimes even interior air quality, and rarely natural or artificial lighting. Little research adds acoustic comfort to the above [43-45]. This is the case despite the fact that noise is one of the most disruptive aspects with health implications for housing sector occupants [46]. Some tools such as IEQ-Compass promise future holistic assessments of indoor environmental comfort considering all the aforementioned aspects [47].

Pending the development of such a tool, some voluntary environmental certificates consider most of these aspects, but are difficult to apply to historic buildings, despite the willingness and trials of some of them, such as LEED-GBC Italy [48-50].

It would be interesting to develop an environmental certificate specifically for protected historic buildings, since this would provide the opportunity to improve their energy efficiency, indoor air quality, and rational use of resources [35,51,52]. Such a concept would significantly approach the sustainability paradigm.

1.2.3. Methods for Establishing Intervention Criteria for Protected Historic Buildings, Achieving a Balance between the Preservation of Cultural Values and Energy Efficiency

The double aim of achieving energy efficiency and IEQ, added to the requirement of preserving the historical and cultural significance of buildings, is extremely complex from the outset, as " ... the derogation regime to national transposition laws is the adopted solution for defining if or if not a historic (i.e., protected) building undergoing to some renovation has to comply with the energy efficiency requirements. This is a no-solution because it introduces differences among EU countries in applying energy efficiency requirements to historic buildings ... " [53] (p. 29).

Some authors have developed methods or guides to combine both objectives, but most legislation exemptions still remain. Existing studies on the subject [54] represent a considerable effort but come up against the difficult objectification of cultural values and their restrictions. As a consequence, they achieve improved energy performance, but never strict compliance with energy retrofitting standards, and they remain far from recent nZEB buildings.

The Effesus European project [55,56] developed a method to assess the impacts of energy efficiency retrofit measures on historic buildings. It assessed six aspects in specific assessment modules: cultural significance, economic return, embodied energy consumption, indoor environment, operational energy consumption, and technical compatibility, and it proposed a five-step method to better qualify the level of heritage significance, based on three assessment types: visual, physical, and spatial. However, it must be pointed out that the very same Effesus partners explained that the methodology would require further development and field-testing.

The EN 16883:2017 Standard for improving the energy performance of historic buildings collected the Effesus project results to provide a holistic approach for energy efficiency in historic buildings, while respecting their heritage significance [57].

The IEA-SCH Task 59 project adapted the assessment criteria included in the aforementioned standard to better support the evaluation of a retrofit solution and facilitate its practical application [58]. Nevertheless, the authors recognize it is still a complex task.

In this context, the paper has as its main objectives:

To reconsider if it is always beneficial that energy efficiency strategies are submitted to heritage protection legislation.

To provide a method to define in a detailed and organized manner the different kind of values that can be found in historic buildings, to objectify them, and to establish an accurate priority ranking when comparing them with those resulting from an intervention to improve the sustainability of the building. This is an important point, as the usual classification of values considers materiality, aesthetics, and spatial characteristics, which means a great quantity of data have to be organized to reach a comprehensive understanding. 
To defend those interventions resulting from the improvement of energy efficiency and Interior Environmental Quality as a new kind of value to show and preserve the sustainability value at the same level as the historic and cultural values.

To expand the literature on heritage energy efficiency and rehabilitation, specifically for multi-family residential buildings under cultural protection.

To achieve these objectives, the paper uses as a case study, the project and retrofitting works of Can Armengol Palace in Palma de Mallorca (Spain). This project has a relevant floor area for housing and achieves a delicate balance between preserving cultural values and improving the building's energy performance

\section{Materials and Methods}

\subsection{Case Study}

Can Armengol Palace is the result of the merger and the retrofitting of two palaces from different historical periods. The first text about the building dates from 1685, though the archaeological remains discovered in the area where the building lies and the inclusion of several gothic elements in its aerial structures would suggest an earlier origin. The center of Figure 1 shows both palaces and their central courtyards. The sum of both palaces comprises the current Can Armengol building.



Figure 1. Aerial view of Can Armengol Palace.

In 1810, a relevant neoclassic remodeling took place that joined both palaces, modified the façades of one of the courtyards, and created several noble rooms decorated with mural paintings on the first floor. Figure 2 shows the aforementioned courtyard façades. 


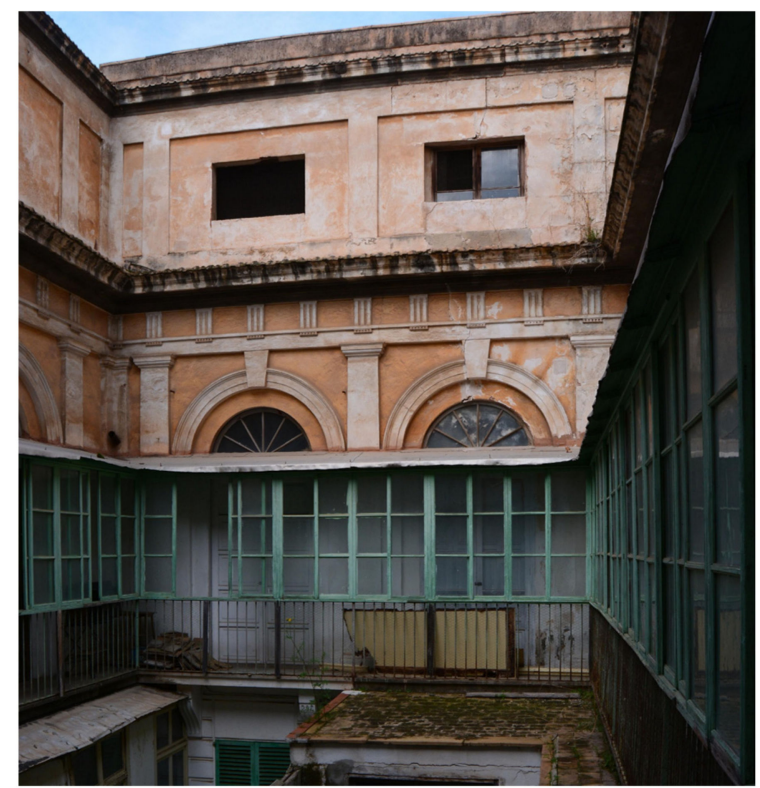

Figure 2. Neoclassical courtyard.

At the beginning of the twentieth century, another significant intervention took place, this time following the Noucentista style. It affected the building perimeter and the height and composition of the south and west façades. Figure 3 shows these façades and the other courtyard of the building.


Figure 3. South façade (left) and noucentista courtyard (right).

Considering its historic and artistic values, the building has been declared of local cultural interest. As a result of this protection, any intervention on the building must be approved by the authorities with jurisdiction for architectural heritage. For this building, the entire envelope has a high protection level and cannot be altered without sound justification. 


\subsection{Method}

Figure 4 synthesizes the steps in the method for assessing and establishing the most suitable criteria to improve to the maximum the energy efficiency of the building, while preserving its cultural values.

\begin{tabular}{|c|c|c|c|c|}
\hline 1 & 2 & 3 & 4 & 5 \\
\hline $\begin{array}{l}\text { PRELIMINARY } \\
\text { STUDIES }\end{array}$ & $\begin{array}{l}\text { ASSESSMENT OF } \\
\text { BUILDING } \\
\text { PERFORMANCE }\end{array}$ & $\begin{array}{l}\text { RECOGNITION } \\
\text { CULTURAL } \\
\text { VALUES }\end{array}$ & $\begin{array}{l}\text { DEFINITION } \\
\text { INTERVENTION } \\
\text { CRITERIA }\end{array}$ & $\begin{array}{l}\text { ANALYSIS OF } \\
\text { INTERVENTION } \\
\text { EFFECTS ON THE } \\
\text { CULTURAL VALUES }\end{array}$ \\
\hline
\end{tabular}

Figure 4. Phases in the method for assessing and recognizing cultural values and defining intervention criteria.

\subsubsection{Preliminary Studies to Obtain General and Detailed Knowledge of the Building}

Contemporary buildings mainly use solutions based on elements comprised of several highly specialized layers. In contrast, historical buildings tend to have a single layer, depending on the context, for example, the weather, the proximity of materials, and traditional local construction techniques. Consequently, every historic building has its own characteristics. Hence, it is vital to find out about the building in depth. In this kind of building, a single element performs multiple roles, such as structural and fire safety and thermal and acoustic protection.

Can Armengol is a historic building that incorporates every strategy of traditional construction in the area. The loading walls are made of Marès stone as vertical elements. Wood beams, vaults, and a dome constitute the horizontal elements.

When the energy performance of the building elements is analyzed, every construction system of the envelope must be studied. The corresponding data are summarized in Tables 1 and 2 .

Table 1. Parameters of thermal performance of opaque elements in their original state.

\begin{tabular}{|c|c|c|}
\hline Element & Configuration & Theoretical Thermal Transmittance \\
\hline Inclined roofs & Wooden beam floor + Marès stone beam filling + Arabic tiles & $2.01 \mathrm{~W} / \mathrm{m}^{2} \mathrm{~K}$ \\
\hline Terraced roofs & $\begin{array}{c}\text { Wooden beam floor + Marès stone beam } \\
\text { filling + slope-providing layer + waterproofing + pavement }\end{array}$ & $1.4 \mathrm{~W} / \mathrm{m}^{2} \mathrm{~K}$ \\
\hline Slabs to ground & Compacted earth + mortar layer + pavement & $1.04 \mathrm{~W} / \mathrm{m}^{2} \mathrm{~K}$ \\
\hline Floor to air, 1 & Stone vault + rubble filling + pavement & $2.07-2.12 \mathrm{~W} / \mathrm{m}^{2} \mathrm{~K}$ \\
\hline Floor to air, 2 & $\begin{array}{l}\text { Wooden or iron beam floor + Marès stone beam } \\
\text { filling + pavement }\end{array}$ & $1.86-1.92 \mathrm{~W} / \mathrm{m}^{2} \mathrm{~K}$ \\
\hline Façades, opaque part & $\begin{array}{l}\text { Masonry walls with blocks of Marès stone, } \mathrm{t}=20-55 \mathrm{~cm} \text {. } \\
\text { Outside layer of lime mortar; inside plaster }\end{array}$ & $2.33-3.21 \mathrm{~W} / \mathrm{m}^{2} \mathrm{~K}$ \\
\hline
\end{tabular}

Table 2. Parameters of thermal performance of transparent elements in their original state.

\begin{tabular}{cccccc}
\hline Configuration & $\begin{array}{c}\text { Theoretical Thermal } \\
\text { Transmittance }\end{array}$ & Solar Factor & Absorptivity & Permeability \\
\hline Windows & Wood frame + single glass & $\begin{array}{c}\text { Glass }=5.7 \\
\text { Frame }=2.0\end{array}$ & 0.85 & 0.7 & $50 \mathrm{~m}^{3} / \mathrm{hm}^{2}$ at $100 \mathrm{~Pa}$ \\
\hline
\end{tabular}

\subsubsection{Assessment of Building Performance}

Based on a deep knowledge of the elements that comprise the building, the feasibility of compliance with current building legislation must be established. Otherwise, alternative solutions must be proposed. 
The current Spanish building code (CTE) establishes that "it can be concluded that strict application of CTE is not feasible [in historic protected buildings] for planning, technical or economic reasons, or incompatibility with the protection degree of the building."

The overall assessment of the building verified that while the original vertical elements met the structural and fire safety requirements, the horizontal elements showed several shortcomings. Moreover, the condition of large areas of the façades was reasonably good, except for moisture on the ground floor, while the roofs and carpentry showed considerable degradation.

Protected buildings are exempt from CTE energy performance requirements. However, in this case, as is often the situation, the developer and future users (who are expected to be foreigners with high purchasing power) had great expectations for the thermal efficiency and comfort of the eight top-end dwellings. Consequently, the software tool LIDER-CALENER HULC [59], accepted by public agents, was used to verify the energy requirements. Figure 5 shows the simulation provided by the aforementioned software at thermal unit level. The different colors mean the different construction elements, for example slabs with steel or wood beams, a key specification for structural considerations but with very little influence on the energy performance.
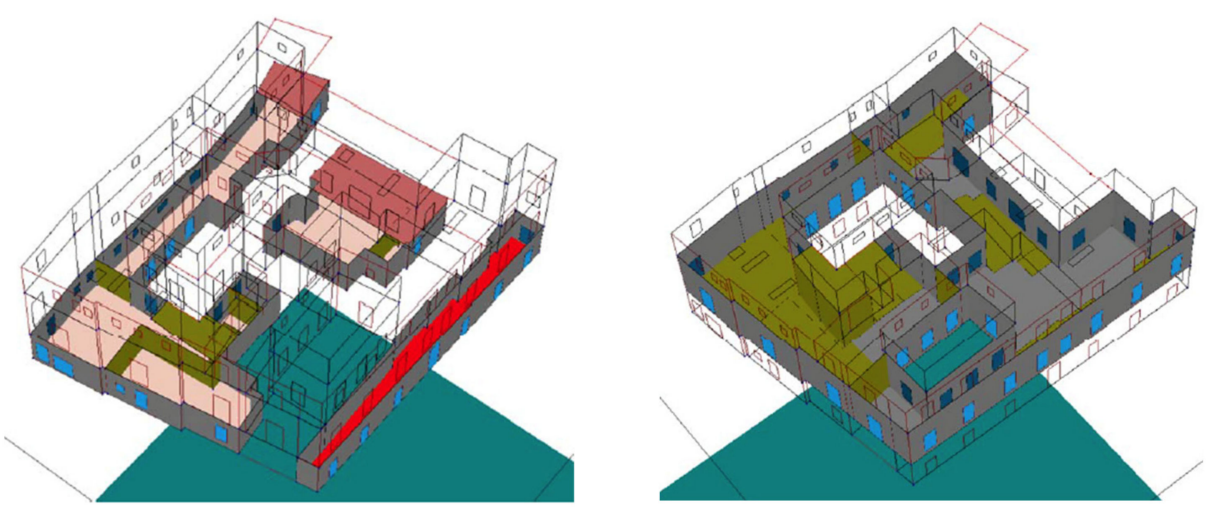

Figure 5. LIDER-CALENER HULC simulation for ground (left) and first floor (right).

The energy demand assessment shows $149.84 \mathrm{kWh} / \mathrm{m}^{2}$ year for the current building, while the simulated model of the building, accomplishing the minimum energy standard, demands $82 \mathrm{kWh} / \mathrm{m}^{2}$ year. Evidently, the building does not meet current energy performance requirements.

A deeper study of energy loses during the winter reveals that they are mainly concentrated in façades that have ventilation, infiltration, and a high value of thermal transmittance.

\subsubsection{Recognition of Cultural Values}

Heritage buildings have diverse cultural values. They may serve as historic documents, symbols of citizenship, or a premise to be rehabilitated and recycled, to avoid generating more waste. Consequently, it is widely accepted that the values to recognize in historic buildings are subjective, documentary, and use [60].

On the basis of a deep knowledge of the building, the elements with the highest cultural values to preserve must be recognized.

As explained before, three groups of values can be distinguished: subjective, documentary, and use.

The subjective values focus on considerations like architectural aesthetics, identity, or iconicity.

Documentary values include aspects like the historic architectural style, the role of the building as a historic document, or anthropology concepts.

Finally, the use values refer to compliance with the requirements stated in current legislation (structural and fire safety and acoustic insulation). Some of these values are shown in Figure 6: subjective values such as the beauty of the views from the building, in 
this case the gothic church of St. Jaume, or the rare slabs with wood beams made from various remains of other beams, or the modernist frescoes on the walls; documentary values as the mural paintings of the first floor, the gothic archaeological remains, or the neoclassical elements; and values of use like the structural vaults, the courtyard cantilever, and the wooden slabs.

a) Subjective values
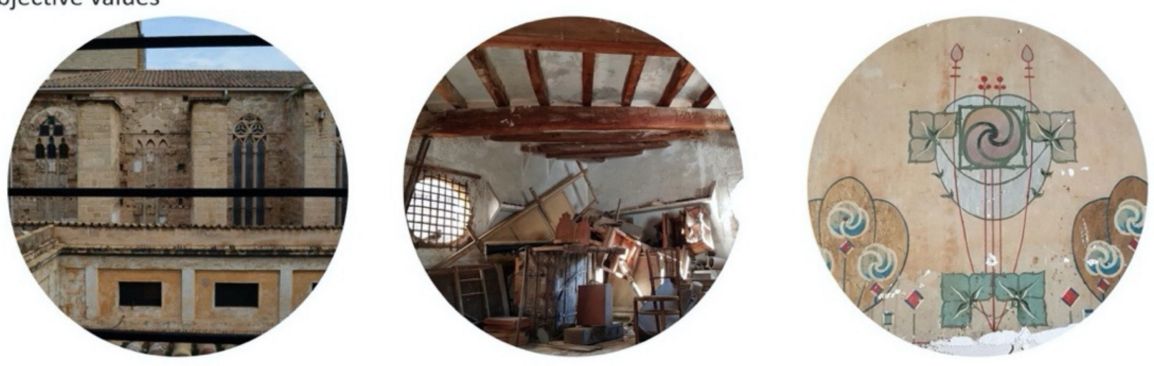

b) Documentary values
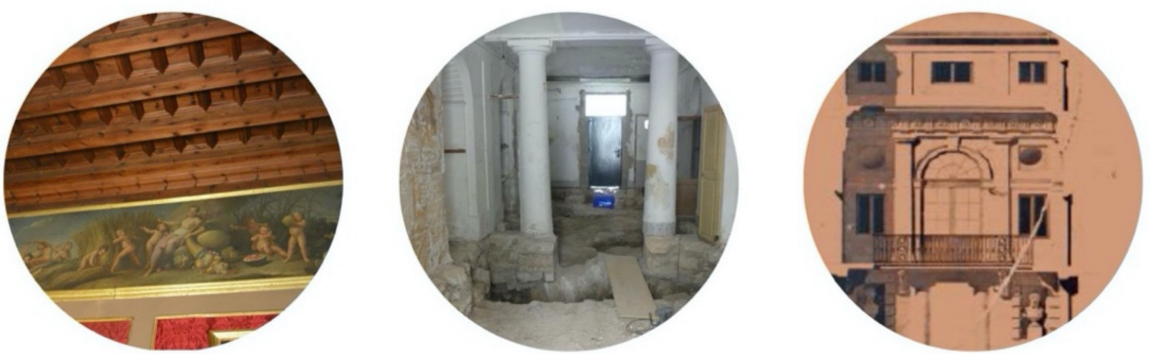

c) Values of use
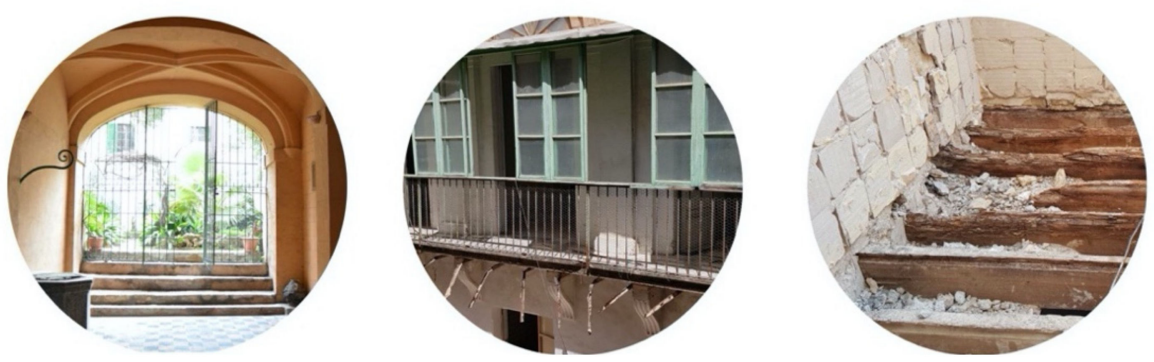

Figure 6. Pictures showing some Can Armengol values from the three groups (a) subjective values, (b) documentary values, (c) values of use.

It is largely accepted that the intervention project and works must center on the preservation of subjective and documentary values. However, it is also accepted that use values could be improved since they do not comply with current legislation. Figure 7 explains the importance of each of these values for the Can Armengol building.

The subjective and documentary values are remarkably high, as much as the use values of the site, the economic value, or the ecology of materials. Nevertheless, the use value regarding compliance with current legislation is significantly low. The challenge consists of improving this last value without altering the rest of the values.

\subsubsection{Definition of Intervention Criteria}

In this phase of the method, overall strategies must be studied that allow the attainment of full compliance or the best possible compliance with the safety, habitability, and functionality requirements defined by current legislation.

The following strategies were adopted to reach a balance between reducing energy demand, improving thermal comfort, and preserving documentary and significance values. 


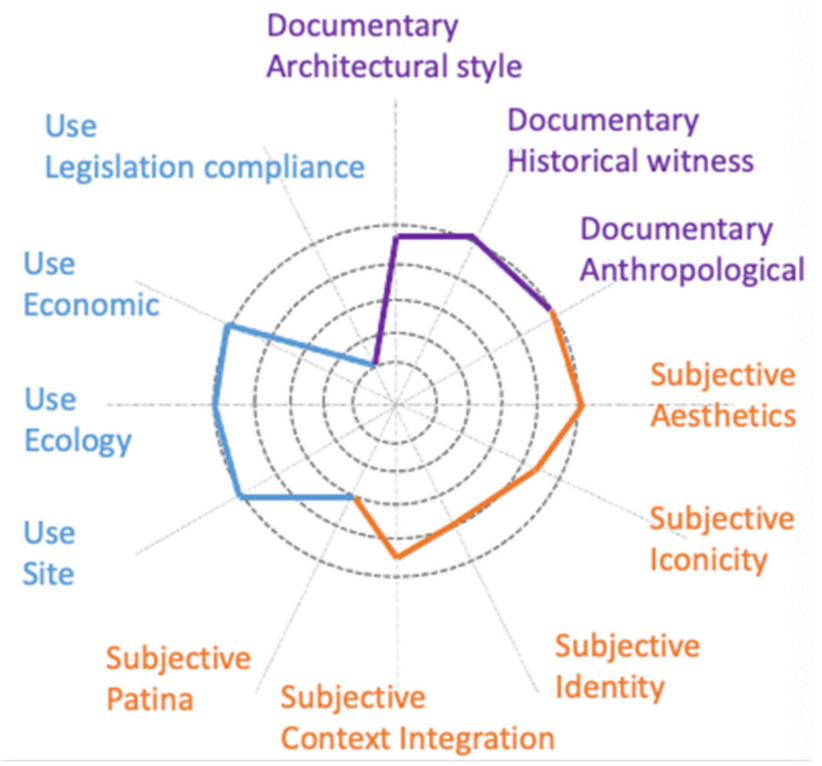

Figure 7. Graphic of Can Armengol values: violet color for documentary values, orange for subjective ones, and blue for use values. The central circle means a score of 0 and the farthest circle means a score of 10, the highest level. This is the authors' interpretation based on deep knowledge of every aspect of the building.

Thermal Insulation

It was applied on the inside layer of façades, roofs, terraces, outer slabs, and elements in contact with the ground. Table 3 shows the most suitable thickness for each element.

Table 3. Final thermal transmittance per element.

\begin{tabular}{ccc}
\hline Construction Element & Insulation Thickness & Total Thermal Transmittance \\
\hline Ground floor slab & $90 \mathrm{~mm}$ & $0.28 \mathrm{~W} / \mathrm{m}^{2} \mathrm{~K}$ \\
\hline Outer slabs & $30 \mathrm{~mm}$ & $0.42 \mathrm{~W} / \mathrm{m}^{2} \mathrm{~K}$ \\
\hline Sloping roofs & $100 \mathrm{~mm}$ & $0.28 \mathrm{~W} / \mathrm{m}^{2} \mathrm{~K}$ \\
\hline Terrace roofs & $100 \mathrm{~mm}$ & $0.22 \mathrm{~W} / \mathrm{m}^{2} \mathrm{~K}$ \\
\hline Façades & $75 \mathrm{~mm}$ & $0.35 \mathrm{~W} / \mathrm{m}^{2} \mathrm{~K}$ \\
\hline
\end{tabular}

Figure 8 details a horizontal section of the façades. The gray layer is the current wall made of Marès stone. The next layer is the water-resistant 30-mm thick thermal insulation, then there is a thin air chamber, another 60 -mm thick thermal insulation, and finally the finishing inside layer. The specific materials used are disclosed within the figure.

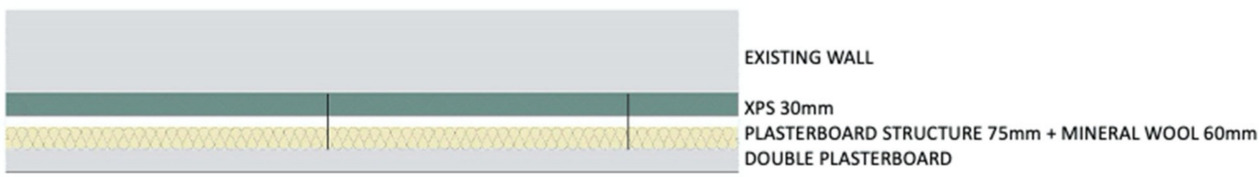

Figure 8. Horizontal section of façades.

Carpentry Substitution

Old windows were replaced with new windows. The wood material and the composition were maintained but the characteristics were improved, including the airtightness and staunchness. This prevents infiltrations of unconditioned exterior air that has a different moisture load to the interior air. Note that the palace is situated on the coast. The glass was replaced to reduce thermal transmittance, as shown in Table 4. 
Table 4. Carpentries standards.

\begin{tabular}{cccc}
\hline & Theoretical Thermal Transmittance & Solar Factor & Permeability \\
\hline $\begin{array}{c}\text { Windows } \\
\text { Low e glass }\end{array}$ & Glass $=1.4$ & 0.45 & $3 \mathrm{~m}^{3} / \mathrm{hm}^{2}$ \\
\hline
\end{tabular}

Ventilation

Mechanical ventilation was implemented with double flux, including a heat recovery system to guarantee energy efficiency and a lower degree of control for the user. Consequently, there was no superficial condensation under any occupation scenario. The thermal insulation placed next to the wall is water-resistant, so that moisture from the interior air cannot cross it and condense on the interior face of the stone walls.

Furthermore, the final interior layer is slightly separated from the floor and the ceiling to allow air circulation within the air chamber. This circulation is fostered by the mechanical ventilation inside the dwellings.

Thermal Facilities

A high-efficiency system was chosen to generate heating, cooling, and sanitary hot water, based on the principle of the aerothermal pump. The installation was decentralized, as an aerothermal system was provided for each home. Each system provides air conditioning and sanitary hot water and is composed of an outdoor unit and an indoor unit equipped with a hot water generation device.

\subsubsection{Analysis of Intervention Effects on Protected Elements of the Building}

The last step relates to the impact of defined global intervention strategies on the cultural values of the building.

Envelope

Thermal insulation placed in the internal face of the envelope avoids any alteration in cultural values, as the ancient stone walls have never shown their materiality.

Carpentries

Carpentries were replaced. The composition and material (wood) were preserved to have the same final image as the original carpentry, with improved properties.

Ventilation

Horizontal ducts were placed inside the new ceilings. These also play a fire protection role. In some parts of the buildings, there are no ceilings so that users can see the original beams. In these areas, air inlets and outlets are located in the perimeter walls of the room.

Vertical ducts were placed inside the historic chimneys.

\section{Thermal Facilities}

To minimize the impact of the facilities, given the kind of building and historical environmental conditions, the outdoor production units and accumulation tanks were placed on the central flat roof of the building, where they cannot be seen from other buildings.

The radiant floor system respects the historical paving that must be preserved. This paving was lifted to reinforce the original beams, then the radiant floor was laid and finally the paving was replaced.

As explained, the chosen strategies for the retrofit of this building are compatible with the strict preservation of subjective and documentary values. Below, the level of energy certificate that can be reached is verified. 


\section{Results}

The aforementioned strategies must be assessed through simulation software to obtain the EPC, according to the Spanish transposition. The software that was used is HULC. It can calculate the energy demand and consumption of the building for required standard thermal conditions by simulating the heating, ventilation, and air conditioning system's (HVAC) performance to obtain the energy rating.

To identify which strategy has the greatest impact, several scenarios were proposed. The first scenario (A) assessed the energy performance of the building in its original state. The second scenario (B) was an intermediate state, with new improved windows, as described before, and thermal insulation for roofs and elements in contact with the ground or the exterior air. The third simulation $(\mathrm{C})$ included the strategies of the previous case and thermal insulation added to the façades. The fourth scenario (D), the one that was carried out, considered every previous strategy and added thermal insulation for every horizontal slab, even between inner spaces. Then, two hypothetical solutions were simulated to improve the final rating. The first (scenario E) was designed to reduce heating demand. The second (scenario F) was aimed at reducing energy consumption.

A. Original state.

Figure 9 shows poor results for heating demand ( $G$ rating) and a medium value for cooling demand ( $\mathrm{D}$ rating). The better rate for the summer can be understood by looking at Figure 2: the proximity to neighboring buildings reduces solar radiation.

B. Intermediate state 1.

Thermal insulation is added to every sloping roof or terrace, and to elements of the building that are in contact with the ground or the external air.

Windows are replaced to incorporate double low-e glass with a low solar factor. In addition, the general characteristics of the wood frame are improved: the airtightness and staunchness. Infiltrations of unconditioned exterior air with a moisture load different from interior air are avoided.

Figure 9 shows that all these actions still provide an unsatisfactory performance level since heating demand remains within the $\mathrm{G}$ rating. However, cooling demand is reduced to reach a $C$ rating.

C. Intermediate state 2 .

In addition to the strategies of scenario $B$, thermal insulation is added in the inside layer of the façades. This considerably reduces the heating demand to reach a $C$ rating, as shown in Figure 9.

D. Executed state.

In this scenario, thermal insulation is added to every horizontal slab.

The performance improves very slightly, as shown in Figure 9.

Although the energy performance of every element of the envelope is improved and the cultural values preserved, the EPC only reaches a $C$ rating.

E. Hypothetical solution of increasing thermal insulation for the façades.

To obtain a B rating for heating demand, as shown in Figure 9, thermal insulation 200-mm thick needs to be added to the façades. This would lead to a considerable reduction in useable floor area, which is not always feasible in old dwellings.

F. Hypothetical approach considering the building located in the Peninsula. 


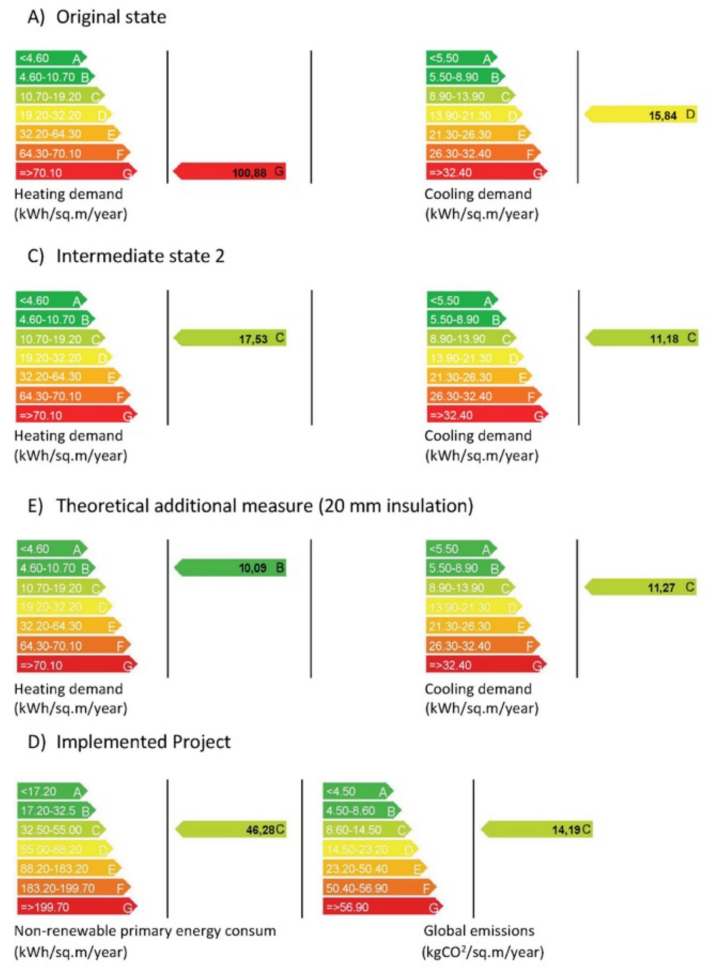

B) Intermediate state 1

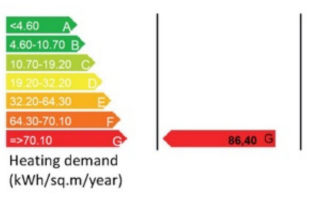

D) Implemented Project

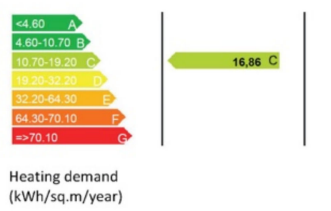

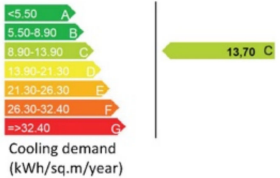

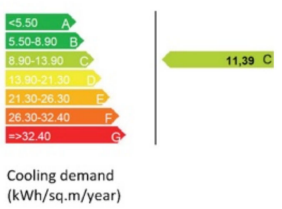

F) Theoretical additional analysis (implemented Project if the building were located at climatic zone B3 - mainland Spain -

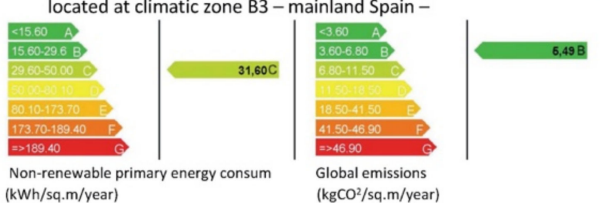

Figure 9. Energy Performance Certificate Ratings for each scenario previously described. Graphics show the rate based on heating and cooling demand (A-E) or the non-renewable primary energy consum and global emissions for scenarios $(\mathbf{D}, \mathbf{F})$. Please note that these graphics are obtained by the Spanish software authorized by the government, and the number commas should be understood as dots.

Energy consumption results are penalized for this building because of its location in Palma de Mallorca, whose conversion factor coefficient for primary electricity is higher than that used in mainland Spain. If Can Armengol were located in an equivalent climatic zone, B3, within mainland Spain, with scenario D corresponding to the implemented project, and we studied not just heating and cooling demand but also non-renewable primary energy consumption and global emissions, a B rating would be reached for carbon emissions, and a $C$ for primary energy consumption, which is closer to a B rating as seen in Figure 9.

We must mention, briefly as it is not the main objective of this paper, the improvements developed on the other IEQ parameters: more natural lighting resulted for the upper floor through discreet skylights on the roof; better interior air quality was achieved by hidden mechanical ventilation; the values of impact and airborne noise were improved up to values above any European legislation. All these factors will be soon developed specifically in another paper.

\section{Discussion}

The results for each scenario are very similar regarding cooling demand. However, heating demand drops sharply when thermal insulation is added to the façades.

As discussed in Section 1.2, a number of experts suggest that adding insulation on the internal side of façades may cause overheating during the summer. However, as previously shown, such overheating was absent from the analyzed case study. These results can be explained by two circumstances: (1) Can Armengol is very close to the adjacent buildings, all of which are of similar height, as is common within historical centers; consequently, there is very little solar gain during the winter and during the summer; and (2) the number of occupants expected for these large dwellings is very low.

As the analysis provided in this paper shows, it is very difficult to attain an A EPC rating in a protected historic building without jeopardizing its cultural values, even when every element of the envelope is improved. If we agree that the improvement in user 
comfort over the EPC rate must be prioritized, what should be considered is that the possible thermal comfort of users is below the usual parameter level, due to satisfaction with and comprehension of the historic building, as past evidence has shown.

From this point, several future lines of research emerge to equate the positive energy conception of new buildings with that of retrofitted historic buildings, and to develop the most suitable methods of assessment, as much to objectify cultural values as to better simulate the energy performance of heritage buildings.

\subsection{Beyond the Energy Efficiency of Historic Buildings}

The efficient energy performance of historic buildings is not enough to define the intervention, as thermal decompensations may exist that could reduce thermal welfare. The latter is not a guarantee of indoor environmental wellbeing, which should include acoustic and lighting comfort as much as indoor air quality. In addition, these parameters must be controllable individually or remotely.

It is also important to monitor the real performance of the building once retrofitting works are finished. This will provide relevant feedback for the design stage. It must be noted that there is a gap in the literature on this point, since most research considers every step towards retrofitting works, but very few have been able to analyze the monitoring data when the building becomes fully operational.

\subsection{A General Approach to Historical Buildings}

Most practitioners consider the measures related to energy performance. This is quite separate from the retrofitting works that heritage buildings require. It is crucial to fully understand the building and the intervention project since every legal requirement affects the others. Moreover, in the context of heritage building retrofitting, other aspects such as structural safety, fire protection, and accessibility also impact indoor environmental comfort solutions and energy performance.

In this regard, an important study was conducted by Dalla Mora et al. [61]. They developed the retrofitting project of a protected historic building to transform it into a prestigious residential complex. The retrofit was primarily aimed at providing seismic safety and improving energy performance. Moreover, the RIBuild European project emphasizes this aspect [8].

\section{Conclusions}

This paper provides evidence of the difficulties in obtaining a high rate of EPC in historic dwellings when the improvement in energy performance must be subordinate to heritage restrictions. It occurs similarly when trying to improve other parameters related to Interior Environment Quality (IEQ), like the air quality or the acoustics.

From that starting point, two routes are possible to provide a viable opportunity for the useful survival of heritage. Both of them intend to include protected buildings in conventional renovation policies for dwellings and to improve their acceptability and, in turn, their preservation. The first one is developing a new EPC rating and process, adapted to the specificities of protected historic buildings, to go beyond envelope thermal performance and consider the compromise required to preserve cultural values. The second one is to consider the paradigm of sustainability to be integrated as another historic layer in protected buildings that express the values, technologies, and materials of contemporary societies, with similar relevance to that posed by past values, technologies, and materials. This integration might have positive outcomes in terms of socioeconomics, demography, and physiology [62].

Complying with regulatory requirements on energy efficiency in heritage buildings should not be an option, but obligatory, with differences between buildings with very high cultural values, mostly with a public use, and all the rest, with a residential use. These last could show their new sustainability values at the same level of the historic ones. In fact, in the future, those values will also be historic. 
Author Contributions: Conceptualization, B.O., A.D. and C.M.-D.; Formal analysis, B.O., A.D. and C.M.-D.; Investigation, B.O., A.D. and C.M.-D.; Methodology, B.O., A.D. and C.M.-D. All authors have read and agreed to the published version of the manuscript.

Funding: This paper was produced in the framework of the EnerValor2 (ref. PID2019-104561RB-I00 MINCIU).

Institutional Review Board Statement: Not applicable.

Informed Consent Statement: Not applicable.

Data Availability Statement: Not applicable.

Acknowledgments: The authors appreciate the contributions of architect Claudio Hernández, curator of Can Armengol Palace.

Conflicts of Interest: The authors declare no conflict of interest.

\section{References}

1. Evangelista, R.; Ramalho, E.A.; Andrade e Silva, J. On the use of hedonic regression models to measure the effect of energy efficiency on residential property transaction prices: Evidence for Portugal and selected data issues. Energy Econ. 2020, 86, 104699. [CrossRef]

2. Sánchez, E.C.; Berrio, S.S.; Perez, B.O.; Marmolejo-Duarte, C. Perceived Benefits of Energy Efficiency in the Spanish Residential Market and Their Relation to Sociodemographic and Living Conditions. Appl. Sci. 2021, 11, 875. [CrossRef]

3. Marmolejo-Duarte, C.; García-Hooghuis, A.; García-Masià, A. ¿Cuánto y por qué estamos dispuestos a pagar por hogares con eficiencia energética? Un análisis de preferencias declaradas en Barcelona. ACE 2020. [CrossRef]

4. Koster, H.R.A.; van Ommeren, J.N.; Rietveld, P. Historic amenities, income and sorting of households. J. Econ. Geogr. 2016, 16, 203-236. [CrossRef]

5. Onecha, B.; Dotor, A. Simulation Method to Assess Thermal Comfort in Historical Buildings with High-Volume Interior Spaces: The Case of the Gothic Basilica of Sta. Maria del Mar in Barcelona. Sustainability 2021, 13, 2980. [CrossRef]

6. Chiesa, G. Bioclimatic Approaches in urban and Building Design, 1st ed.; Springer: Berlin/Heidelberg, Germany, 2021.

7. Available online: https:/ / ec.europa.eu/energy/eu-buildings-database_en (accessed on 6 February 2021).

8. RIBuild_D6.2_v0.1. H2020-EE-03-2014. Written Guidelines for Decision Making Concerning the Possible Use of Internal Insulation in Historic Buildings. 2020. Available online: https:/ / www.ribuild.eu/about-ribuild (accessed on 4 July 2021).

9. Bottino-Leone, D.; Larcher, M.; Herrera-Avellanosa, D.; Haas, F. Evaluation of natural-based internal insulation systems in historic buildings through a holistic approach. Energy 2019, 181, 521-531. [CrossRef]

10. Galatioto, A.; Ricciu, R.; Salem, T.; Kinab, E. Energy and economic analysis on retrofit actions for Italian public historic buildings. Energy 2019, 176, 58-66. [CrossRef]

11. Cornaro, C.; Puggioni, V.A.; Strollo, R.M. Dynamic simulation and on-site measurements for energy retrofit of complex historic buildings: Villa Mondragone case-study. J. Build. Eng. 2016, 6, 17-28. [CrossRef]

12. Akkurt, G.G.; Aste, N.; Borderon, J.; Buda, A.; Calzolari, M.; Chung, D.; Costanzo, V.; del Pero, C.; Evola, G.; Huerto-Cardenas, H.E.; et al. Dynamic thermal and hygrometric simulation of hitorical buildings: Critical factors and possible solutions. Renew. Sustain. Energy Rev. 2020, 118, 109509. [CrossRef]

13. Huerto-Cardenas, H.E.; Leonforte, F.; Aste, N.; del Pero, C.; Evola, G.; Costanzo, V.; Lucchi, E. Validation of dynamic hygrothermal simulation models for historical buildings: State of the art, research challenges and recommendations. Build. Environ. 2020, 180, 107081. [CrossRef]

14. Lucchi, E.; Delera, A.C. Enhancing the Historic Public Social Housing through a User-Centered Design-Driven Approach. Buildings 2020, 10, 159. [CrossRef]

15. Caro, R.; Sendra, J.J. Are the dwelling of historic Mediterranean cities cold in winter? A field assessment on their door environment and energy performance. Energy Build. 2020, 230, 110567. [CrossRef]

16. Blázquez, T.; Ferrari, S.; Suárez, R.; Sendra, J.J. Adaptive approach-based assessment of a heritage residential complex in southern Spain for improving comfort and energy efficiency through passive strategies: A study based on a monitored flat. Energy 2019, 181, 504-520. [CrossRef]

17. Andersen, R.K.; Fabi, V.; Corgnati, S. Predicted and actual indoor environmental quality: Verification of occupants' behaviour models in residential buildings. Energy Build. 2016, 127, 105-115. [CrossRef]

18. Webb, A.L. Energy retrofits in historic and traditional buildings: A review of problems and methods. Renew. Sustain. Energy Rev. 2017, 77, 748-759. [CrossRef]

19. Salem, R.; Bahadori-Jahromi, A.; Mylona, A.; Godfrey, P.; Cook, D. Investigating the potential impact of energy-efficient measures for retrofitting existing UK hotels to reach the nearly zero energy building (nZEB) standard. Energy Effic. 2019, 12, 1577-1594. [CrossRef]

20. Ciulla, G.; Galatioto, A.; Ricciu, R. Energy and economic analysis and feasibility of retrofit actions in Italian residential historical buildings. Energy Build. 2016, 128, 649-659. [CrossRef] 
21. Kisilewicz, T. On the role of external walls in the reduction of energy demand and the mitigation of human thermal discomfort. Sustainability 2019, 11, 1061. [CrossRef]

22. Zhou, X.; Carmeliet, J.; Derome, D. Influence of envelope properties on interior insulation solutions for masonry walls. Build. Environ. 2018, 135, 246-256. [CrossRef]

23. Andreotti, M.; Calzolari, M.; Davoli, P.; Pereira, L.D.; Lucchi, E.; Malaguti, R. Design and Construction of a New Metering Hot Box for the In Situ Hygrothermal Measurement in Dynamic Conditions of Historic Masonries. Energies 2020, 13, 2950. [CrossRef]

24. Martínez-Molina, A.; Tort-Ausina, I.; Cho, S.; Vivancos, J.L. Energy efficiency and thermal confort in historic buildings: A review. Renew. Sustain. Energy Rev. 2016, 61, 70-85. [CrossRef]

25. Assem, E.O. Correlating thermal transmittance limits of walls and roofs to orientation and solar absorption. Energy Build. 2011, 43, 3173-3180. [CrossRef]

26. Asan, H. Investigation of wall's optimum insulation position from maximum time lag and minimum decrement factor point of view. Energy Build. 2000, 32, 197-203. [CrossRef]

27. Aste, N.; Angelotti, A.; Buzzettin, M. The influence of external walls thermal inertia on the energy performance of well insulated buildings. Energy Build. 2009, 41, 1181-1187. [CrossRef]

28. Gagliano, A.; Patania, F.; Nocera, F.; Signorello, C. Assessment of the dynamic thermal performance of massive buildings. Energy Build. 2013, 72, 361-370. [CrossRef]

29. Roque, E.; Vicente, R.; Almeida, R.; da Silva, J.M.; Ferreira, A.V. Thermal characterization of traditional Wall solution of built heritage using the simple hot box-heat flow meter method: In situ measurements and numerical simulation. Appl. Therm. Eng. 2020, 169, 114935. [CrossRef]

30. Dotor, A.; González, J.L.; Olona, J.; Onecha, B. Eficiència energética i valors partrimonials: Conflictes i solucions. L 'Informatiu 2013, 336, 84-87.

31. Evola, G.; Marletta, L.; Natarajan, S.; Patanè, E.M. Thermal inertia of heavyweight traditional buildings: Experimental measurements and simulated scenarios. Energy Procedia 2017, 133, 42-52. [CrossRef]

32. Gagliano, A.; Nocera, F.; Patania, F.; Moschella, A.; Detommasso, M.; Evola, G. Synergic effects of thermal mass and natural ventilation on the thermal behavior of traditional massive buildings. Int. J. Sustain. Energy 2014. [CrossRef]

33. Piasecki, M.; Radziszewska-Zielina, E.; Czerski, P.; Fedorczak-Cisak, M.; Zielina, M.; Krzysciak, P.; Kwasniewska-Sip, P.; Grzeskowiak, W. Implementation of the Indoor Environmental Quality (IEQ) Model for the Assessment of a Retrofitted Historical Masonry Building. Energies 2020, 13, 6051. [CrossRef]

34. Ortiz, M.; Itard, L.; Bluyssen, P.M. Indoor environmental quality related risk factors with energy-efficient retrofitting of housing: A literature review. Energy Build. 2020, 221, 110102. [CrossRef]

35. Magrini, A.; Franco, G. The energy performance improvement of historic buildings and their environmental sustainability assessment. J. Cult. Herit. 2016, 21, 834-841. [CrossRef]

36. Shrubsole, C.; Hamilton, I.G.; Zimmermann, N.; Papachristos, G.; Broyd, T.; Burman, E.; Mumovic, D.; Zhu, Y.; Lin, B.; Davies, M. Bridging the gap: The need for a system thinking approach in understanding and addressing energy and environmental performance in buildings. Indoor Built Environ. 2019, 18, 100-117. [CrossRef]

37. Kamaruzzaman, S.N.; Egbu, C.O.; Ahmad, E.M.; Shah, A.; Irfan, A. The effect of indoor environmental quality on occupants perception of performance: A case study of refurbished historic buildings in Malaysia. Energy Build. 2011, 43, 407-413. [CrossRef]

38. Fabbri, K.; Tronchin, L. Indoor environmental quality in low energy buildings. Energy Procedia 2015, 78, 2778-2783. [CrossRef]

39. Lucchi, E. Review of preventive conservation in museum buildings. J. Cult. Herit. 2018, 29, 180-193. [CrossRef]

40. Fabbri, K.; Bonora, A. Two new índices for preventive conservation of the cultural heritage: Predicted risk of damage and heritage microclimate risk. J. Cult. Herit. 2021, 47, 208-217. [CrossRef]

41. Pereira, L.D.; Tavares, V.; Soares, N. Up-to-Date Challenges for the COnservation, Rehabilitation and Energy Retrofitting of Higher Education Cultural Heritage Buildings. Sustainability 2021, 13, 2061. [CrossRef]

42. Geng, Y.; Ji, W.; Lin, B.; Zhu, Y. The impact of thermal environment on occupant IEQ perception and productivity. Build. Environ. 2017, 121, 158-167. [CrossRef]

43. Hobday, R. Indoor Environmental Quality in Refurbishment; Historic Scotland Technical Paper 12; Publishing Historic Environment Scotland: Edinburgh, UK, 2011.

44. Halliday, S. Indoor Air Quality and Energy Efficiency in Traditional Buildings; Historic Scotland Technical Paper 6; Publishing Historic Environment Scotland: Edinburgh, UK, 2009.

45. Audenaert, G.L.A.; Braet, J.; Fabbri, K.; Weeren, A. Sybtgetuc Scan and Simultaneous Index aimed at the Indoor Environmental Quality evaluation and certification for people and artworks in heritage buildings. Energy Procedia 2015, 78, 1365-1370. [CrossRef]

46. Alonso, A.; Patricio, J.; Suárez, R.; Escandón, R. Acoustical retrofit of existing residential buildings: Requirements and recommendations for sound insulation between dwellings in Europe and other countries worldwide. Build. Environ. 2020, $174,106771$. [CrossRef]

47. Larsen, T.S.; Rohde, L.; Honsson, K.T.; Rasmussen, B.; Jensen, R.L.; Knudsen, H.N.; Witterseh, T.; Bekö, G. IEQ-Compass-A tool for holistic evaluation of potential indoor environmental quality. Build. Environ. 2020, 172, 106707. [CrossRef]

48. Suk-Kyung, K. Indoor Environmental Quality Assessment of Historic Buildings in the State park: A Case Study in Michigan. J. Sustain. Dev. 2018, 11. [CrossRef] 
49. Boarin, P.; Dotor, A.; Onecha, B. New horizons of sustainability for historic heritage restoration with high cultural values. The case study of Sant Manuel pavilion of Hospital de Sant Pau in Barcelona. Recuperoeconservazione 2014, 112, 22.

50. Mazzola, E.; Mora, T.D.; Peron, F.; Romagnoni, P. An Integrated Energy and Environmental Audit Process for Historic Buildings. Energies 2019, 12, 3940. [CrossRef]

51. Boarin, P.; Lucchi, E.; Zuppiroli, M. An Assessement Method for Certified Environmental Sustainability in the Preservation of Historic Buildings. A Focus on Energy Efficiency and Indoor Environmental Quality in the Italina Experience of GBC Historic Building. Restor. Build. Monum. 2019. [CrossRef]

52. Tadeu, S.; Rodrigues, C.; Tadeu, A.; Freire, F.; Simoes, N. Energy retrofit of historic buildings: Environmental assessment of cost-optimal solutions. J. Build. Eng. 2015, 4, 167-176. [CrossRef]

53. Mazzarella, L. Energy retrofit of historic and existing buildings. The legislative and regulatory point of view. Energy Build. 2015, 95, 23-31. [CrossRef]

54. Ruggeri, A.G.; Calzolari, M.; Scarpa, M.; Gabrielli, L.; Davoli, P. Planning energy retrofit on historic building stocks: A score-driven decision support system. Energy Build. 2020, 224, 110066. [CrossRef]

55. Eriksson, P.; Hrabovszky-Horváth, S.; Hermann, C.; Rodwell, D. EFFESUS Methodology for Assessing the Impacts of EnergyRelated Retrofit Measures on Heritage Significance. Hist. Environ. Policy Pract. 2014, 5, 132-149. [CrossRef]

56. Hermann, C.; Rodwell, D. Heritage significance assessments to evaluate retrofit impacts: From heritage values to characterdefining elements in praxis. In How to Assess Built Heritage? Assumptions, Methodologies, Examples of Heritage Assessment Systems; International Scientific Committee for Theory and Philosophy of Conservation and Restoration ICOMOS, Romualdo Del Bianco Foundatione, Lublin University of Technology: Lublin, Poland, 2015; pp. 169-190. ISBN 978-83-940280-3-9.

57. European Standard EN16883:2017 Conservation of Cultural Heritage. In Guidelines for Improving the Energy Performance of Historic Buildings, Provides a Holistic Approach to Energy Efficiency in Historic Buildings; Official Spanish Version: UNE-EN 16883; Pub. AENOR: Madrid, Spain, 2018.

58. Buda, A.; de Place Hansen, E.J.; Rieser, A.; Giancola, E.; Pracchi, V.N.; Mauri, S.; Marincioni, V.; Gori, V.; Fouseki, K.; López, C.S.P.; et al. Conservation-Compatible Retrofit Solutions in Historic Buildings: An Integrated Approach. Sustainability 2021, $13,2927$. [CrossRef]

59. LIDER-CALENER (HULC) v.2.0.2203.1160. Available online: https:/ /www.codigotecnico.org/Programas/HerramientaUnificada LIDERCALENER.html (accessed on 4 July 2021).

60. Onecha, B.; Genís, M.; González, J.L.; Casals, A.; Portal, J.; Morros, J. Las Claves de la Rehabilitación y Restauración Arquitectónica. Volumen 1: El Método Sistémico Aplicado a la Intervención en Edificios Existentes; Universitat Politecnica de Catalunya: Barcelona, Spain, 2018; ISBN 978-84-09-04305-7.

61. Mora, T.D.; Cappelletti, F.; Peron, F.; Romagnoni, F.; Bauman, F. Retrofit of an historical building toward NZEB. Energy Procedia 2015, 78, 1359-1364. [CrossRef]

62. Wilson, C.; Dowlatabadi, H. Models of Decision Making and Residential Energy Use. Annu. Rev. Environ. Resour. 2007, 32, 169-203. [CrossRef] 